\title{
The use of artificial benthic collectors for assessment of spatial patterns of settlement of megalopae of Carcinus maenas (L.) (Brachyura: Portunidae) in the lower Mira Estuary, Portugal
}

\author{
José Paula*, Inês C. Silva, Sara M. Francisco \& Augusto A. V. Flores \\ IMAR - Laboratório Marítimo da Guia, Departamento de Biologia Animal, Faculdade de Ciências da \\ Universidade de Lisboa, Estrada do Guincho, 2750-642 Cascais, Portugal \\ (*Author for correspondence: Tel.: +351-214869211; Fax: +351-214869720; E-mail: jpaula@fc.ul.pt)
}

Key words: megalopae, settlement, artificial collectors, spatial patterns, Carcinus maenas, Mira estuary

\begin{abstract}
Artificial benthic collectors have been widely used for the assessment of settlement rates of decapod crustaceans. However, to date no consistent works have addressed spatial patterns of settlement in different estuarine habitats, and no specific studies targeted the interaction of artificial surfaces with the surrounding natural substrate. It may be expected that the artificial surface may produce a different thigmotactic response when compared to the natural substrate, which may limit the use of this technique for assessment of natural settlement rates. In this study the settlement rates of megalopae of the estuarine crab Carcinus maenas were addressed, specifically deploying artificial benthic collectors in different habitats both intertidal and subtidal in the lower Mira estuary. A number of experiments were performed concerning stratification and temporal fluctuations of settlement. Further, the interaction of collector surface with the surrounding substrate was investigated, by comparing settlement rates in natural and artificial substrates in different habitats. Results have shown significant differences in settlement between different estuarine habitats, both in spatially replicated experiments and in a high-resolution temporal experiment. However, comparison between settlement rates in artificial and natural substrates has shown that there is a strong interference between collectors and surrounding substrate, limiting interpretation of results concerning settlement rates in artificial substrate alone.
\end{abstract}

\section{Introduction}

Most estuarine brachyuran crabs have a pelagic larval phase, which is exported to shelf waters. When the megalopa stage is reached, the animals face the problem of returning to inshore waters and find appropriate habitats to settle (Shanks, 1998). The megalopae penetrate in estuaries and accomplish landwards movement by selective tidal stream transport (Shanks, 1995; Forward et al., 1997; Queiroga, 1998), which is a complex interaction between behaviour (mainly cyclic shifts in vertical position) and physical mechanisms (the tidal cycle and baroclinic water mass movements). Settlement is viewed as the transition process between the pelagic and benthic phases, and occurs as megalopae reach adequate habitats (Rodríguez et al., 1993; Hunt \& Scheibling, 1997). According to Rodríguez et al. (1993) the process of settlement in marine invertebrates involves two separate steps: 1) an active behavioural search of adequate substrate, and 2) residence or fixation to the substrate which triggers the juvenile moult. The acquisition of a capacity of thigmotactic response 
is generally considered as megalopal competency (Goodrich et al., 1989; Jensen, 1991; Rodríguez et al., 1993). Megalopae competent for settling present a remarkable plasticity in advancing or delaying their moult in the face of the presence or absence of given stimuli, such as conspecifics, predators or various structural and chemical characteristics of the substrate (e.g. O'Connor, 1993; Strasser \& Felder, 1999). Megalopae thus show a strong adaptation to actively search and choose an adequate habitat for the juvenile phase (Sulkin \& van Heukelem, 1986; Wolcott \& DeVries, 1994).

Concerning the types of settlement stimuli, visual, tactic and chemical cues have been actually verified or hypothesised (see below). Other factors such as microscale current patterns may modulate megalopal settlement response, as passive sinking is not viewed as a major cause (Hedvall et al., 1998). Instead, it seems that active selection by megalopae is the major factor influencing early juvenile distribution, at least in intertidal crabs (e.g. Paula et al., 2001, 2003). Megalopae of Callinectes sapidus Rathbun, 1896 react negatively to predator odour and positively to seagrass environments (Welch et al., 1997). Salinity (Wolcott \& DeVries, 1994) and other estuarine waterborne cues (Wolcott \& DeVries, 1994; Forward et al., 1997) have also been suggested as guides to recruiting megalopae. Other authors showed that megalopae of several species prefer structurally complex substrates, which provide shelter (e.g. O'Connor, 1993; Eggleston \& Armstrong, 1995; Hedvall et al., 1998; Moksnes et al., 1998; Stevens \& Kittaka, 1998). These substrates include vegetation (Boström \& Bonsdorff, 1997) and shelly gravel (Welch et al., 1997). The presence of conspecifics may enhance settlement in Uca spp. (O’Connor, 1993), and several authors referred a number of substrate stimuli capable to accelerate the moult to the first juvenile stage (e.g. O'Connor, 1991; Wolcott \& DeVries, 1994; Gebauer et al., 1998; Strasser \& Felder, 1999).

Artificial collectors are common tools for studying settlement rates of decapod crustaceans, such as 'hog's hair' filter surfaces (e.g. van Montfrans et al., 1995; Paula et al., 2001) and artificial seaweeds (Phillips, 1972; Phillips \& Booth, 1994). These devices intend to simulate the adequate typical settlement grounds (facilitating collection) or to enhance settlement by inducing a positive thigmotactic response as providing refuge. Floating cylindrical artificial collectors have been widely used, covered by a 'hog's hair' filter surface (see van Montfrans et al., 1990 for general methods), especially addressing settlement rates of the portunid blue crab C. sapidus (eg Goodrich et al., 1989; van Montfrans et al., 1990; Boylan \& Wenner, 1993; Wrona et al., 1995; Hasek \& Rabalais, 2001), but also in African mangroves (Paula et al., 2001). The question whether settlement rates thereby obtained actually reflect effective settlement in appropriate areas was not specifically addressed in any of the referred studies. Alternatively, it may be conceived that those settlement rates are a function of megalopal availability in the water mass, being the presence of megalopae on the collectors' surface a temporary event. However we may expect that they do reflect rates of immigration of megalopae from shelf waters into the estuary. Nevertheless megalopal competency to settle may not be achieved by reaching estuarine waters, as suggested by Paula et al. (2001). Unpublished own results indicate that a delay between immigration of megalopae and effective settlement within estuarine benthic habitats does take place in Carcinus maneas (Linnaeus, 1758).

In most cases, collection of megalopae of benthic invertebrates in their natural settling grounds is a difficult or impossible task, due to the small size of the animals and their tendency to prefer structured bottoms that provide refuge. Paula et al. (2003) used unfolded 'hog's hair' surfaces to study benthic settlement of brachyuran crabs in a tropical mangrove, obtaining clear temporal and spatial patterns over different mangrove areas. However, collector efficiency in the different areas was not studied. Flores et al. (2002) used nets under boulders for studying settlement rates of the rocky intertidal crabs Pachygrapsus marmoratus (Fabricius, 1787) and Xantho incisus (Leach, 1814). In this case the natural boulder substrate was used as collecting surface and thus interference with collection method was considered minimal. The possibility of using a natural substrate for collection is however limited to particular environments. Also, the rates of settlement in natural substrates are often low, and less effort is made if suitable surfaces enhancing settlement are used. Settlement intensity in artificial surfaces will 
not necessarily reflect actual rates in the natural substrate, as its physical nature may in fact decrease or enhance preference by settling megalopae, and thus modulate their thigmotactic response. If megalopae are selective for types of structure or complexity of natural surfaces, then deployment of structured artificial collectors on unstructured bottoms should enhance settlement rates, as widely observed in artificial hard reefs deployed in soft bottoms. It is thus very likely that artificial surfaces hardly reflect natural absolute rates of settlement within an area, and its interference with varying background environment should make spatial comparisons very doubtful.

The main objective of this research was to assess spatial patterns of settlement of megalopae of the crab $C$. maenas in different estuarine habitats, both intertidal and subtidal, at the lower section of the Mira Estuary, south-western Portugal. It was further investigated whether settlement rates on artificial collectors are influenced by the interaction between artificial surfaces and the complexity of the surrounding substrate.

Carcinus maenas is the most common crab in European estuaries, widely distributed in intertidal and subtidal shallow environments. The life cycle of the species comprises an exported planktonic larval phase, which is rapidly flushed out to shelf waters by ebbing currents after release (Queiroga et al., 1994; Queiroga, 1996). Megalopae migrate back to the estuary during spring tides, and transport is accomplished by selective tidal stream transport (Berrill, 1982; Queiroga, 1998; Hedvall et al., 1998; Moksnes et al., 1998). According to Hedvall et al. (1998) and Moksnes et al. (1998) there are indications that opportunistic behaviour is expressed already at settlement, as several different habitats may provide appropriate settling grounds.

\section{Materials and methods}

\section{Study area}

The Mira Estuary is located in the south-western Portuguese mainland coast (approximately between $37^{\circ} 40^{\prime} \mathrm{N}$ and $8^{\circ} 45^{\prime} \mathrm{W}$ ), extending for a length of around $40 \mathrm{~km}$ from the mouth to the limit of tidal influence (see Fig. 1). Tides are semi-diurnal, with

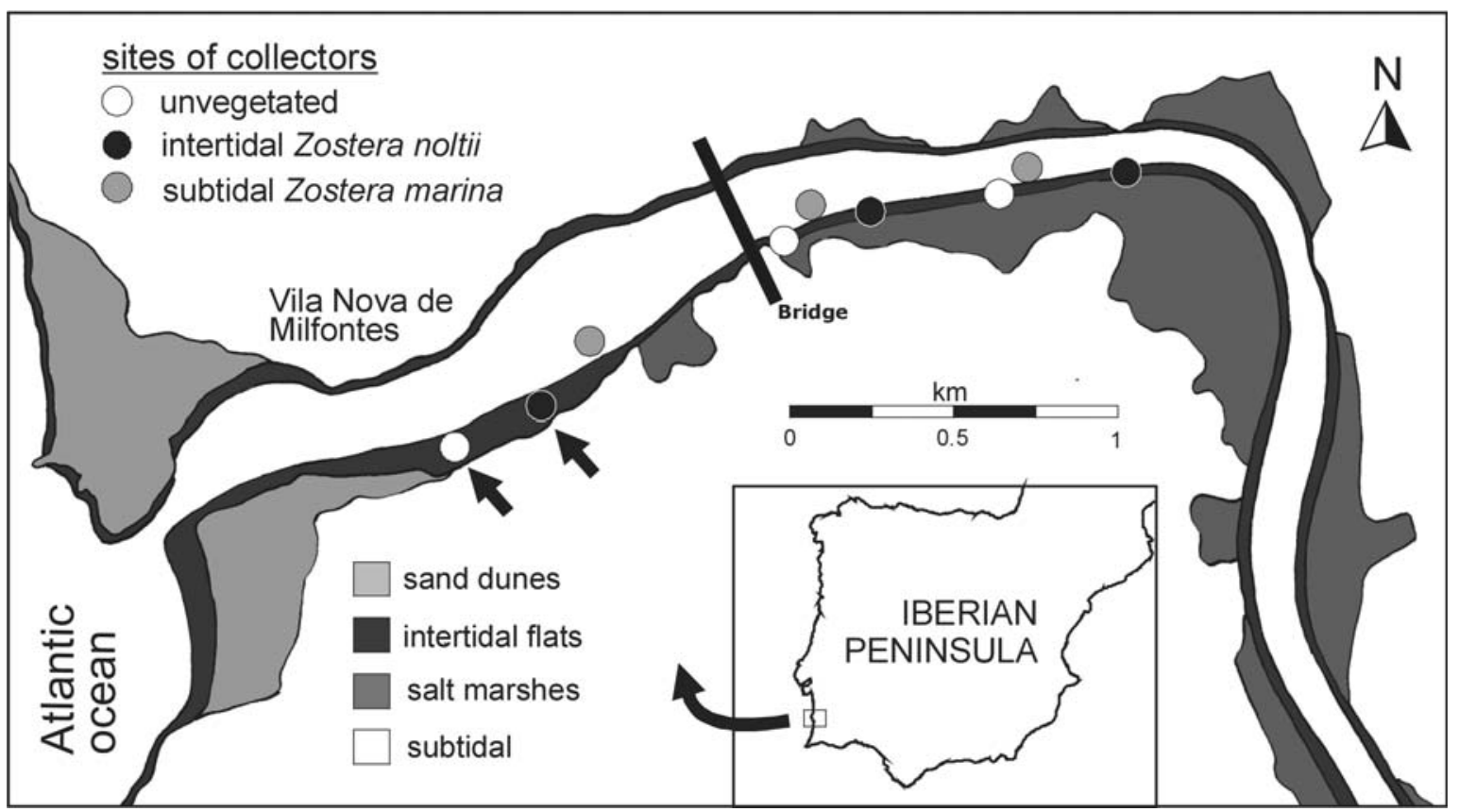

Figure 1. Map of lower Mira Estuary showing sites of collecting of Carcinus maenas megalopae. Arrows indicate sites used for temporal series and comparison between natural and artificial substrates. 
an amplitude of around $1 \mathrm{~m}$ during neap tides and $3 \mathrm{~m}$ during spring tides. Tidal penetration varies between around $7.5 \mathrm{~km}$ and $2.5 \mathrm{~km}$ during respectively average spring and neap tides (Paula, 1998). There is a relatively strong stratification of the water column during the neap tide period, and an almost complete vertical homogenisation during spring tides due to turbulence (Paula, 1998; Blanton \& Andrade, 2001).

The lower section of the estuary has a maximum of $400 \mathrm{~m}$ width and a maximum depth of between 5 and $10 \mathrm{~m}$. Due to low riverine input, this part of the estuary has a dominant marine character. The intertidal zone is dominated by areas with varying density cover of the seagrass Zostera noltii Hornemann, 1832 and bare sandy muddy substrates. Near to $Z$. noltii habitats, the shallow subtidal zone is dominated by dense cover of the seagrass Zostera marina Linnaeus, 1752.

\section{Field methods}

\section{Stratified spatial settlement}

The experiment to study the rates of settlement on different estuarine habitats was designed with a nested approach, using as habitats (treatments) intertidal $Z$. noltii, intertidal bare substrate and subtidal $Z$. marina. For each habitat, three different random areas were selected, each with three randomly deployed replicates in each treatment. The experiment was repeated in two different random starting dates, both during neap-tide 5-d periods (as this was the observed period of maximum settlement, own unpublished data) within the breeding period of $C$. maenas. The measure of settlement was the daily number of settled megalopae in individual collectors. Twenty-seven collectors were deployed each day.

The collectors were made of 'hog's hair' filter, with a dimension of $50 \times 40 \mathrm{~cm}$ and $2.5 \mathrm{~cm}$ thick, attached to a metal frame and deployed flat on the substrate (see Fig. 2). Preliminary observations have shown that the weight of the metal frame was enough to prevent any movement of the collectors with the currents. Also the coverage of the collector surface by sand, seagrass, algae or debris was found neglectable, and initial intention of using wide mesh boxes to prevent this was abandoned. For the subtidal zone, an additional fine mesh was collocated underneath the 'hog's hair' surface, to avoid loss when lifting collectors for sampling; also, these three replicate collectors were

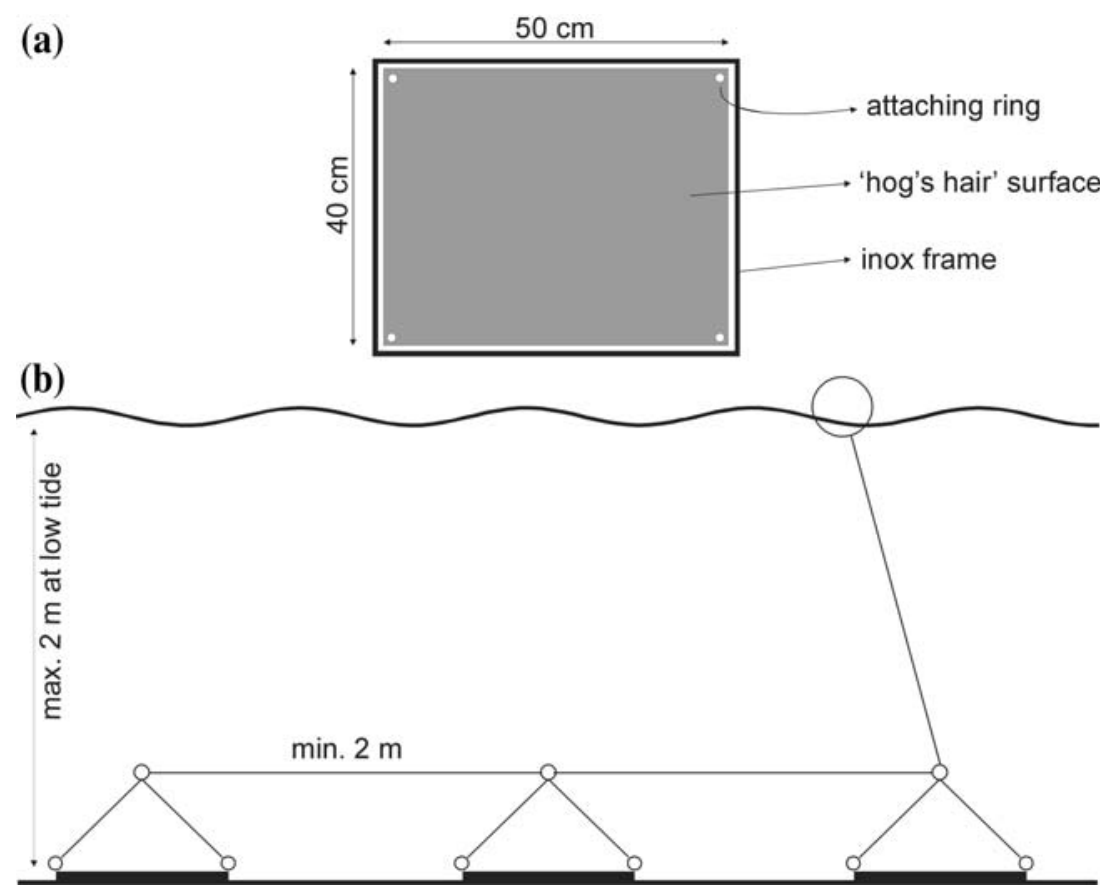

Figure 2. Diagrammatic top view of collector (a) and of scheme of deployment of subtidal series of collectors (b, not to scale). 
attached to each other with a $2-\mathrm{m}$ rope between collectors and a terminal buoy. The distance between collectors was set so that when lifting a collector the next one would remain undisturbed at the bottom.

Collectors were changed each day, during the diurnal low tide, thus remaining in the field during two complete tidal cycles. Collectors were collocated in plastic bags and transported rapidly to the laboratory for immediate processing.

\section{Temporal comparison}

Previously referred intertidal habitats were then used for a longer temporal comparison, by randomly deploying four replicate collectors in $Z$. noltii meadows and unvegetated substrate. The experiment lasted for 2 months between 22 March and 22 May 2002. General field procedures were similar to those described in the previous experiment, and sampling was carried out on a daily basis at diurnal low tide.

\section{Artificial collectors versus natural substrate}

A specific experiment was performed in order to test whether collector efficiency is comparable to rates of settlement in the natural surrounding substrate. In this experiment, two different intertidal substrates were chosen: unvegetated sandy mud and seagrass $Z$. noltii meadow. In both substrates, four random replicate collectors were deployed. In addition, four sampling plots of equivalent size were delimited on natural substrate, not defaunated, in which megalopae were sorted out from the 2-cm upper layer. In this case, bare sand was sieved in the field with a $0.5 \mathrm{~mm}$ mesh sieve and seagrass cover was detached from within the plots. All this material was placed in labelled plastic bags and preserved in 4\% neutralised formalin until sorting. The experiment was repeated during four dates, coinciding with peak settlement periods.

\section{Laboratory procedure}

Megalopae were removed from the collectors' surface by rinsing in abundant freshwater. Detached material, included all debris, were immediately screened under a binocular microscope. Megalopae of C. maenas from collectors and sediment samples were preserved in $4 \%$ neutralised formalin, and identified using the descriptions by Rice \& Ingle (1975) and Ingle (1992).

\section{Data treatment}

Balanced analyses could not be performed in all cases because collectors were eventually lost in the stratified experiment. Replicates from different sites were pooled for increased robustness of the analysis, but the spatial scales used (replication within and between sites) incorporated the possible variability at different spatial scales. In addition, Bartlett's, Shapiro-Wilk and Cochran tests (Zar, 1996) indicated heteroscedasticity of data in all analyses and thus non-parametric tests, either the Kruskal-Wallis or the Mann-Whitney procedure, were conducted (Sokal \& Rohlf, 1995). In case of significant differences between groups of data, the Dunn's test was used to identify between-group contrasts.

\section{Results}

\section{Stratified spatial settlement}

On average, 23 megalopae collector ${ }^{-1} \mathrm{day}^{-1}$ settled during the first period, while during the second period the mean was 31 (Fig. 3). This difference was found to be significant $(H=10.985$, $p=0.0009)$, showing temporal instability of megalopal supply. The mean number of megalopae collected at the intertidal unvegetated habitat was higher than in the other vegetated substrates during both sampling periods, with settlement rates being estimated at 39 and 62 megalopae collector $^{-1} \mathrm{day}^{-1}$, respectively. At the intertidal Zostera noltii meadow the means were 16 and 10 respectively, while at the subtidal $Z$. marina meadow the means were 8 and 22 respectively. Settlement on the unvegetated areas was significantly higher than on the other areas $(H=58.6905$, $p<0.001$ ), and no statistical differences were found between intertidal and subtidal seagrass meadows. The sampling design used three replicate zones within the lower Mira estuary (see Fig. 1 and Materials and methods section). Comparison of settlement between these areas has shown no statistical differences $(H=0.4313, p=0.806)$. 


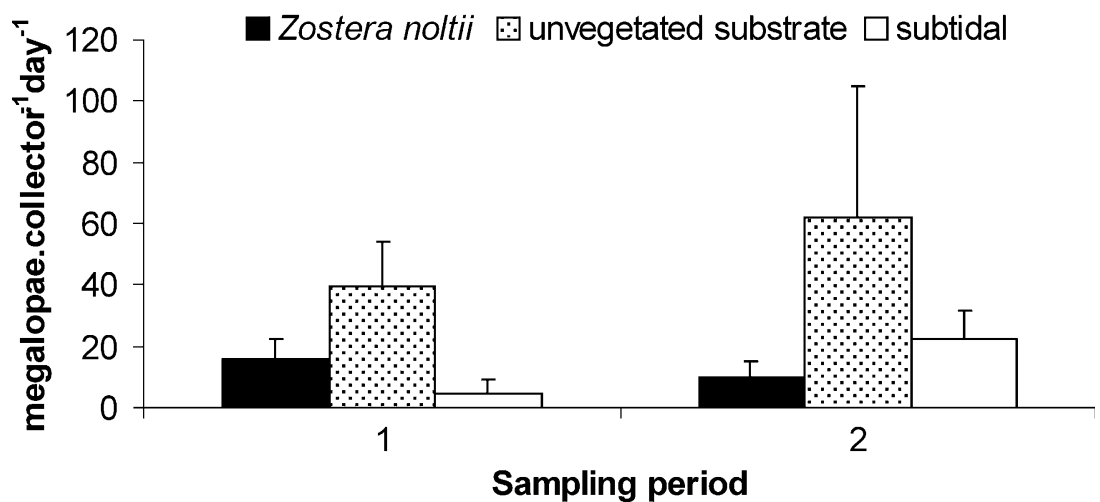

Figure 3. Mean number of collected megalopae of Carcinus maenas in the three different bottom types and during both sampling periods for stratified settlement. Error bars $=$ SE

\section{Temporal comparison}

As in the previous study, the collectors deployed on the unvegetated substrate presented higher settlement rates, although significant only during discrete semi-lunar peaks of settlement intensity during neap tides (Fig. 4). Maximum mean daily values were around 126 megalopae collector $^{-1}$ day $^{-1}$ in unvegetated substrate and 25 within the $Z$. noltii meadow. A comparison of the means of both series has revealed a significant difference (Mann-Whitney $U=1.340, p<0.05$ ).

\section{Artificial collectors versus natural substrate}

Significant differences were found in the unvegetated substrate between artificial and natural substrates $(H=26.5945, p<0.001$, mean settlement values 36 and 4 , respectively), and between artifi- cial collectors at both habitats (Fig. 5). Settlement contrasts between artificial and natural substrates within the $Z$. noltii were not significant ( 7 and 3 megalopae collector ${ }^{-1}$ day $^{-1}$, respectively).

\section{Discussion}

The present results suggest that $C$. maenas megalopae settle preferentially on collectors deployed in unvegetated (unstructured) substrates, when compared to those deployed in seagrass meadows. These results apparently contradict data on settlement of C. sapidus (Olmi et al., 1990). Furthermore, Welch et al. (1997) found that megalopae are attracted by chemical cues of seagrasses, and Forward et al. (1997) have shown that such cues induce a reduction of the duration for moulting in megalopae of $C$. sapidus. Seagrass

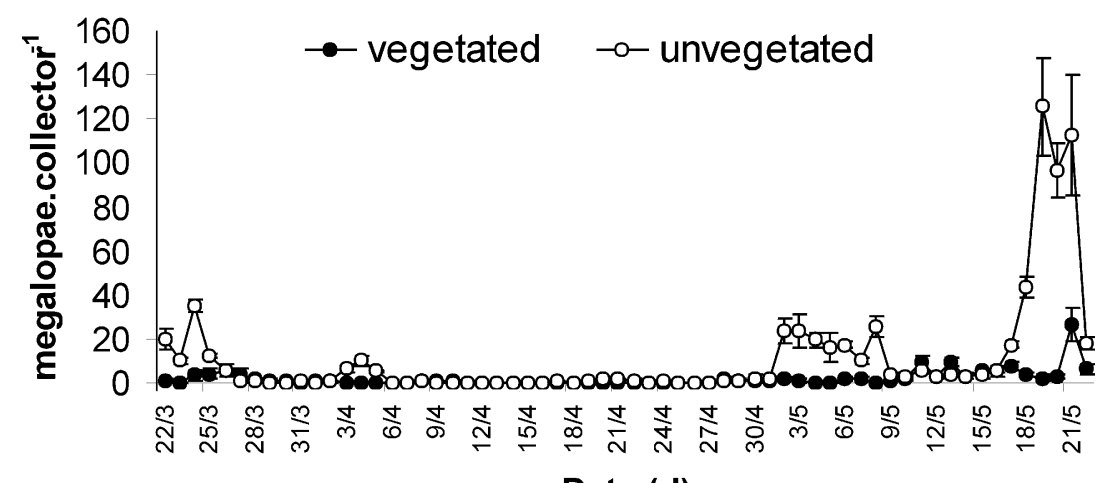

Date (d)

Figure 4. Temporal fluctuation of Carcinus maenas megalopal settlement in artificial collectors deployed at intertidal Zostera noltii meadow and unvegetated bottom. Error bars $=\mathrm{SE}$. 


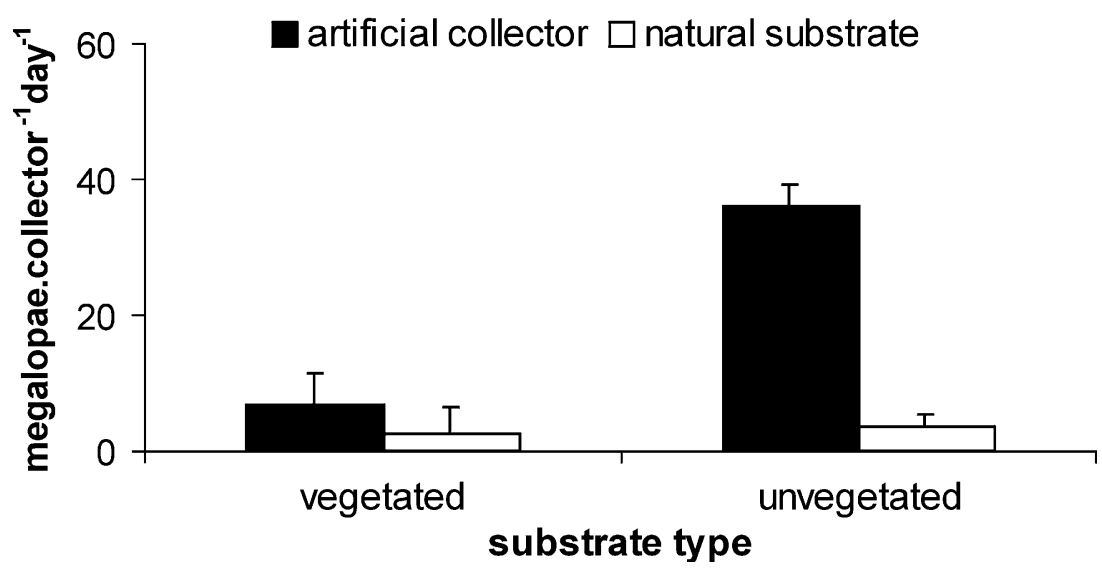

Figure 5. Comparison of settlement of megalopae of Carcinus maenas in artificial collectors and natural substrate deployed at intertidal Zostera noltii meadow and unvegetated bottom. Error bars $=\mathrm{SE}$.

meadows provide structural and chemical cues which may enhance settlement, such as complexity, food, organic content, lower current speed, higher refuge and stability (Boström \& Bonsdorff, 1997). Hedvall et al. (1998) showed that megalopae of C. maenas avoid unstructured substrates such as sand. In these types of substrate the predation rates are very high, reaching, according to Moksnes et al. (1998), more than $80 \%$ in 2 days. The synthetic fibbers of the collector surface provide shelter to prevent predation and trap organic matter that may further enhance settlement. On the other hand, the collectors also attract juveniles, which are otherwise dispersed over the unvegetated substrate of the tidal flat. Since megalopae may be attracted by conspecifics, the presence of juveniles in the collectors may further enhance settlement of megalopae (O'Connor, 1993).

Previous studies using 'hog's hair' coated collectors (e.g. Goodrich et al., 1989; van Montfrans et al., 1990; Boylan \& Wenner, 1993; Wrona et al., 1995; Hasek \& Rabalais, 2001) suggest that this type of sampling reflect natural settlement rates and respective temporal intensity patterns. Strictly on a temporal basis it may be true, but when spatial patterns are concerned, the present results make this statement very doubtful. These authors used floating collectors deployed in the water column and not in appropriate settling grounds; whether collected megalopae were competent to recognise appropriate natural settlement cues remains to be assessed.
The validity of the comparison between the rates of settlement obtained in natural and artificial substrates remains also to be clarified. A number of confounding effects may operate, which suggest lines for future investigation. The fact that the natural substrate was not defaunated prior to experiment could have biased the numbers obtained in the third experiment, namely involving post-settlement processes of longer period than the 24-h of artificial collector deployment. However, a few studies describe a rapid moult to first crab instar after settlement (e.g. Paula et al., 2003), especially in the presence of adequate habitat or cues. It is thus most probable that megalopae collected in natural substrate are from settlement during the previous $24 \mathrm{~h}$. Other studies demonstrate that megalopae of C. maenas may utilize the artificial substrates temporarily, and in fact that most will show a high rate of emigration even if close to moult (Moksnes \& Wennhage, 2001). However this last study used floating collectors, which more likely will collect non-competent megalopae that may exhibit thigmotactic behaviour in the water mass. Further studies are required to elucidate this issue.

In summary, the relative efficiency of artificial collectors clearly depends on the nature of the surrounding habitat. This study strongly suggests that artificial surfaces should be used with caution, at least when deployed in the benthos, and specially when any sort of spatial variability is expected to be studied. 


\section{Acknowledgements}

This study was part of the project 'ProRecruit Shelf processes controlling recruitment to littoral populations in an eastern oceanic boundary: using barnacles and crabs as models', financed by Fundação para a Ciência e Tecnologia (FCT), Portugal, contract no. POCTI/1999/BSE/36663. AAVF acknowledges a post-doc grant by FCT, reference SFRH/BPD/7189/2001. The authors would like to thank the organisers of the 8th Colloquium Crustacea Decapoda Mediterranea for the invitation to JP to present a plenary lecture, which included these data. A sincere acknowledgement is due to Mr. Ilídio Silva for his help with field work, and to Ana Margarida Dinis for her friendly field and laboratory assistance.

\section{References}

Berrill, M., 1982. The life cycle of the green crab Carcinus maenas at the northern end of its range. Journal of Crustacean Biology 2: 31-39.

Blanton, J. O. \& F. A. Andrade, 2001. Distortion of tidal currents and the lateral transfer of salt in a shallow coastal plain estuary. Estuaries 24: 467-480.

Boström, C. \& E. Bonsdorff, 1997. Community structure and spatial variation of benthic invertebrates associated with Zostera marina (L.) beds in the northern Baltic Sea. Journal of Sea Research 37: 153-166.

Boylan, J. M. \& E. L. Wenner, 1993. Settlement of brachyuran megalopae in a South Carolina, USA, estuary. Marine Ecology Progress Series 97: 237-246.

Eggleston, D. B. \& D. A. Armstrong, 1995. Pre- and postsettlement determinants of estuarine dungeness crab recruitment. Ecological Monographs 65: 193-216.

Flores, A. A. V., J. Cruz \& J. Paula, 2002. Temporal and spatial patterns of settlement of brachyuran crab megalopae at a rocky coast in central Portugal. Marine Ecology Progress Series 229: 207-220.

Forward Jr, R. B., J. Swanson, R. A. Tankersely \& J. M. Welch, 1997. Endogenous swimming rhythms of blue crab, Callinectes sapidus, megalopae: effects of offshore and estuarine cues. Marine Biology 127: 621-628.

Gebauer, P., I. Walter \& K. Anger, 1998. Effects of substratum and conspecific adults on the metamorphosis of Chasmagnathus granulate (Dana) (Decapoda: Grapsidae) megalopae. Journal of Experimental Marine Biology and Ecology 223: 185-198.

Goodrich, D. M., J. van Montfrans \& R. J. Orth, 1989. Blue crab megalopal influx to Chesapeake Bay: evidence for a wind-driven mechanism. Estuarine, Coastal and Shelf Science 29: 247-260.
Hasek, B. E. \& N. N. Rabalais, 2001. Settlement patterns of brachyuran megalopae in a Louisiana estuary. Estuaries 24: 796-807.

Hedvall, O., P.-O. Moksnes \& L. Pihl, 1998. Active habitat selection by megalopae and juvenile shore crabs Carcinus maenas: A laboratory study in annular flume. Hydrobiologia 376: 89-100.

Hunt, H. L. \& R. E. Scheibling, 1997. Role of early post-settlement mortality in recruitment of benthic marine invertebrates. Marine Ecology Progress Series 155: 269-301.

Ingle, R., 1992. Larval Stages of Northeastern Atlantic Crabs An Illustrated Key. Chapman and Hall, London.

Jensen, G. C., 1991. Competency, settling behaviour and postsettlement aggregation by pocelain crab megalopae (Anomura: Porcellanidae). Journal of Experimental Marine Biology and Ecology 153: 49-61.

Moksnes, P.-O. \& H. Wennhage, 2001. Methods for estimating decapod larval supply and settlement: Importance of larval behavior and development stage. Marine Ecology Progress Series 209: 257-273.

Moksnes, P.-O., L. Pihl \& J. van Montfrans, 1998. Predation on postlarvae and juveniles of the shore crab Carcinus maenas: importance of shelter, size and cannibalism. Marine Ecology Progress Series 166: 211-225.

O'Connor, N. J., 1991. Flexibility in timing of the metamorphic molt by fiddler crab megalopae Uca pugilator. Marine Ecology Progress Series 68: 243-247.

O'Connor, N. J., 1993. Settlement and recruitment of the fiddler crabs Uca pugnax and U. pugilator in a North Carolina, USA, salt marsh. Marine Ecology Progress Series 93: 227234.

Olmi, E. J., III, J. van Montfrans, R. N. Lipcius, R. J. Orth \& P. W. Sadler, 1990. Variation in planktonic availability and settlement of blue crab megalopae in the York River; Virginia. Bulletin of Marine Science 46: 230-243.

Paula, J., 1998. Larval retention and dynamics of the prawns Palaemon longirostris $\mathrm{H}$. Milne Edwards and Crangon crangon Linnaeus (Decapoda, Caridea) in the Mira estuary, Portugal. Invertebrate Reproduction and Development 33: 221-228.

Paula, J., T. Dray \& H. Queiroga, 2001. Interaction of offshore and inshore processes controlling settlement of brachyuran megalopae in Saco mangrove creek, Inhaca Island (South Mozambique). Marine Ecology Progress Series 215: 251260.

Paula, J., M. Dornelas \& A. A. V. Flores, 2003. Stratified settlement and moulting competency of brachyuran megalopae in Ponta Rasa mangrove swamp, Inhaca Island (Mozambique). Estuarine, Coastal and Shelf Science 56: 325-337.

Phillips, B. F., 1972. A semi-quantitative collector of the puerulus larvae of the western rock lobster Panulirus longipes cygnus George (Decapoda, Palinuridea). Crustaceana 22: 147-154.

Phillips, B. F. \& J. D. Booth, 1994. Design, use, and effectiveness of collectors for catching the puerulus stage of spiny lobsters. Reviews in Fisheries Science 2: 255-289.

Queiroga, H., 1996. Distribution and drift of the crab Carcinus maenas (L.) (Decapoda, Portunidae) larvae over the 
continental shelf off northern Portugal in April 1991. Journal of Plankton Research 18: 1981-2000.

Queiroga, H., 1998. Vertical migration and selective tidal stream transport in the megalopas of the crab Carcinus maenas. Hydrobiologia 375/376: 137-149.

Queiroga, H., J. D. Costlow \& M. H. Moreira Jr, 1994. Larval abundance patterns of Carcinus maenas (Decapoda, Brachyura) in Canal de Mira (Ria de Aveiro, Portugal). Marine Ecology Progress Series 113: 63-72.

Rice, A. L. \& R. W. Ingle, 1975. The larval development of Carcinus maenas (L.) and C. mediterraneus Czerniavsky (Crustacea, Brachyura, Portunidae) reared in the laboratory. Bulletin of the British Museum (Natural History) Zoology 28: 101-119.

Rodríguez, S. R., F. P. Ojeda \& N. C. Inestrosa, 1993. Settlement of benthic marine invertebrates. Marine Ecology Progress Series 97: 193-207.

Shanks, A. L., 1995. Mechanisms of cross-shelf dispersal of larval invertebrates and fish. In McEdward, L. (ed.) Ecology of Marine Larvae. CRC Press, Boca Raton: 323-367.

Shanks, A. L., 1998. Abundance of post-larval Callinectes sapidus, Penaeus spp., Uca spp., and Libinia spp. collected at an outer coastal site and their cross-shelf transport. Marine Ecology Progress Series 168: 57-69.

Sokal, R. R. \& K. J. Rohlf, 1995. Biometry. The Principles and Practice of Statistics in Biological Research (3rd ed.). W. H. Freeman and Company, New York.

Stevens, B. G. \& J. Kittaka, 1998. Postlarval settling behavior, substrate preference and time to metamorphosis for red king crab Paralithodes camtschaticus. Marine Ecology Progress Series 167: 197-206.

Strasser, K. M. \& D. L. Felder, 1999. Sand as a stimulus for settlement in the ghost shrimp Callichirus major (Say) and $C$. islagrande (Schmitt) (Crustacea: Decapoda: Thalassinidea). Journal of Experimental Marine Biology and Ecology 239: 211-222.

Sulkin, S. D. \& W. F. van Heukelem, 1986. Variability in the length of the megalopal stage and its consequences to dispersal and recruitment in the portunid crab Callinectes sapidus Rathbun. Bulletin of Marine Science 39: 269-278.

van Montfrans, J., C. A. Peery \& R. J. Orth, 1990. Daily, monthly and annual settlement patterns by Callinectes sapidus and Neopanope sayi megalopae on artificial collectors deployed in the York River, Virginia: 1985-1988. Bulletin of Marine Science 46: 214-229.

van Montfrans, J., C. E. Epifanio, D. M. Knott, R. N. Lipcius, D. J. Mense, K. S. Metcalf, III E. J. Olmi, R. J. Orth, M. H. Posey, E. L. Wenner \& T. L. West, 1995. Settlement of blue crab megalopae in western Atlantic estuaries. Bulletin of Marine Science 57: 834-854.

Welch, J. M., D. Rittschof, T. M. Bullock \& R. B. Forward Jr, 1997. Effects of chemical cues on settlement behaviour of blue crab Callinectes sapidus postlarvae. Marine Ecology Progress Series 154: 143-153.

Wolcott, D. L. \& M. C. DeVries, 1994. Offshore megalopae of Callinectes sapidus: depth of collection, molt stage and response to estuarine cues. Marine Ecology Progress Series 109: 157-163.

Wrona, A. B., R. G. Wiegeri \& T. D. Bishop, 1995. Initial report of settlement patterns of brachyuran megalopae at Sapelo Island, Georgia, U.S.A. Bulletin of Marine Science 57: 807-820.

Zar, J. H., 1996. Biostatistical Analysis (3rd ed.). Prentice Hall International Editors, New Jersey. 